\title{
Profil Literasi Sains Dasar Dan Kecenderungan Berpikir Kritis Siswa Smp Di Kabupaten Sumbawa Barat
}

\author{
Rizka Donny Agung Saputra ${ }^{1}$, A. Wahab Jufri², Agus Ramdani ${ }^{3}$ \\ ${ }^{1-3}$ Program Studi Magister Pendidikan IPA, Program Pascasarjana
}

\author{
*Corresponding Author: Rizka \\ Donny Agung Saputra, \\ Program Studi Magister \\ Pendidikan IPA, Program \\ Pascasarjana, \\ Email: \\ rizkadonny202@yahoo.com
}

\begin{abstract}
Abstrak :Literasi sains dasar dan kecenderungan berpikir kritis merupakan kompetensi yang penting untuk dipetakan sejak dini. kedua kompetensi siswa tersebut harus dianalisa perkembangannya dan senantiasa harus selalu dikembangkan karena sangat diperlukan oleh siswa kita agar mampu bersaing pada abad 21 nantinya. Penelitian ini bertujuan untuk melihat profil tingkat kemampuan Literasi sains dasar dan kecenderungan berpikir kritis siswa SMP di Kabupaten Sumbawa Barat (KSB) dan untuk mengetahui hubungan antara kemampuan literasi sains dasar dan kecenderungan berpikir kritis siswa. Penelitian ini adalah penelitian deskriptif kuantitatif. 347 siswa dijadikan subjek penelitian untuk pengukuran tingkat literasi sains dasar dan 333 siswa dijadikan subjek penelitian dalam pengukuran kecenderungan berpikir kritis. Data dikumpulkan menggunakan tes literasi sains dasar dan tes kecenderungan berpikir kritis. Untuk mengetahui profil literasi sains dasar dan kecenderungan berpikir kritis siswa, data penelitian dianalisis secara deskriptif, sedangkan data mengenai hubungan antara tingkat literasi sains dasar dengan kecenderungan berpikir kritis siswa dianalisis Pearson Product-Moment Correlation. Hasil penelitian ini menunjukkan bahwa 1) kemampuan literasi sains dasar siswa SMP di kabupaten Sumbawa Barat, NTB berada pada kategori rendah sedangkan kecenderungan berpikir kritis termasuk pada kategori kuat, dan 2) terdapat hubungan positif yang signifikan antara literasi sains dasar dengan kecenderungan berpikir kritis siswa.
\end{abstract}

Keywords: Profil, Literasi Sains Dasar, Kecenderungan Berpikir Kritis.

\section{Pendahuluan}

Literasi sain dan kecenderungan berpikir kritis merupakan modal intelektual yang harus dimiliki oleh generasi muda dalam abad 21. Kedua aspek ini adalah komponen kunci dalam pendidikan sains yang sangat perlu mendapat perhatian dalam rangka mempersiapkan peserta didik agar mampu berpikir dan menjadi anggota masyarakat yang bertanggungjawab dalam perkembangan ilmu dan teknologi dewasa ini. Literasi sains adalah kemampuan untuk memahami proses-proses ilmiah sains dan terlibat secara fisik dan mental dengan informasi-informasi terkait sains dalam kehidupan sehar-hari. Laugksch (2000) menyatakan bahwa individu dengan kemampuan literasi sains yang tinggi akan cenderung memberikan dukungan pada perkembangan sains dan mampu memberikan penjelasan secara sistematis dan ilmiah mengenai fenomena atau isu-isu sains. Beberapa dekade terakhir, literasi sains telah menjadi salah satu topik diskusi menarik di kalangan para peneliti, pendidik, dan pemerhati pendidikan IPA (Ardianto, 2016). Arohman, et al (2011) menyatakan bahwa literasi sain penting bagi generasi masa depan agar mampu berpikir dan bersikap ilmiah dalam mengkomunikasikan ilmu dan hasil penelitian kepada masyarakat umum. Literasi sains telah menjadi salah satu indikator mutu pendidikan khususnya di Negara-negara anggota OECD dan beberapa Negara partisipan termasuk Indonesia melalui program PISA (Programme for International Student Assessment). Oleh karena itu literasi sains telah diakui secara internasional sebagai tolak ukur tinggi-rendahnya kualitas pendidikan (Ardianto, 2016). Berdasarkan hasil tes PISA, dapat dinyatakan bahwa kemampuan litearsi sains siswa yang berusia sekitar 15 tahun (SMP) di 
Indonesia lebih rendah dibandingkan dengan pelajar sebaya dari Negara-negara lain. Selama tiga periode terakhir tes PISA, rata-rata skor literasi sains pelajar di Indonesia secara berturut-turut adalah 383 pada 2009, 382 pada 2012, dan 403 pada tes PISA tahun 2015. Posisi Indonesia di antara negara-negara lain berada pada peringkat 61 dari 66 pada tahun 2009, peringkat ke 64 dari 65 pada tahun 2012, dan peringkat ke 61 dari 63 negara pada tahun 2015 (OECD, 2009a; OECD 2009b; OECD, 2012). Penelitian skala kecil yang dilakukan oleh Arif, et al., (2016) juga menunjukkan bahwa literasi sains siswa SMP di Sumedang Jawa Barat tergolong masih rendah.Rendahnya tingkat litearsi sains juga ditemukan pada h. mahasiswa calon guru tingkat sekolah dasar (Fakhriyah, et al., 2017) dan mahasiswa calon guru sekolah menengah (Jufri, et al., 2016).

Kecenderungan berpikir kritis adalah bagian penting dari modal intelektual yang dibutuhkan oleh generasi masa depan. Tafazzoli, et al., (2015) menyatakan bahwa kecenderungan berpikir kritis dapat didefinisikan sebagai disposisi personal atau kebiasaan yang mempengaruhi keputusan atau kemampuan untuk mengontrol diri seseorang dalam rangka menyelesaikan masalah berkaitan dengan situasi professional. Facione (2011), menjelaskan bahwa kecenderungan berpikir kritis merupakan semangat kekritisan atau kecenderungan untuk berpikir kritis yang memiliki karakteristik keingintahuan mendalam, ketajaman pemikiran, ketekunan mengembangkan akal, kebutuhan atas informasi yang dipercaya. Sehingga kecenderungan berpikir kritis akan mendorong seseorang untuk mengaplikasikan kompetensi nerpikir kritis dalam setiap aspek kehidupan. Cakupan kecenderungan berpikir kritis dapat meliputi keterampilan kognitif dan kecenderungan bersikap. Sehubungan dengan itu, maka kecenderungan berpikir kritis meruakan rencana bersikap pada diri seseorang berkaitan dengan keterampilan berpikir kritis. Seseorang yang memiliki kecenderungan berpikir kritis akan menunjukkan adanya rasa ingin atahu yang tinggi, antusiame intelektual, berdedikasi untuk mengemukakan alas an melakukan suatu tindakan, sangat mengharapkan informasi-informsi penting, dan memiliki kecenderungan untuk menggunakan keterampilan berpikir kritis dibandingan dengan individu yang memiliki kecenderungan berpikir kritis rendah. Secara umum dapat dinyatakan bahwa kecenderungan berpikir kritis mengacu pada kecenderungan pada pola-pola tertentu dari perilaku intelektual yang konsisten atau perilaku yang dapat teramati dalam situasi tertentu (Kwon, et al., 2007).

Sebagai bahan pertimbangan untuk mengambil kebijakan terkait peningkatan mutu pendidikan, maka sekolah dan pemerintah daerah membutuhkan data mengenai profil kemampuan literasi sains dasar dan kecenderungan berpikir kritis siswa. Dalam hal ini, telah dilakukan penelitian yang bertujuan untuk memetakan profil literasi sains dasar dan kecenderungan berpikir kritis siswa di Kabupaten Sumbawa Barat provinsi Nusa Tenggara Barat.

\section{Metode}

Penelitian ini merupakan penelitian deskriptif yang dilaksanakan dengan teknik survey dan dilakukan di Kabupaten Sumbawa Barat. Populasi penelian ini adalah siswa kelas VIII dan kelas IX SMA yang berjumlah 4.934 dan tersebar di 8 sekolah. Kedelapan sekolah dikelompokkan ke dalam 2 zona yakni zona dalam kota dan luar kota). Sampel penelitian berjumlah 347 orang (173 lakilaki dan 174 perempuan) yang dipilih dengan teknik Cluster Random Sampling.

Data literasi sains dasar siswa dikumpulkan dengan menggunakan Test of Basic Scientific Literacy yang dikembangkan oleh Lauskgsch, dkk. (1996) yang terdiri dari 110 butir tes objektif dengan alternatif jawaban benar, salah, dan tidak tahu. Tes telah diterjemahkan ke dalam Bahasa Indonesia oleh peneliti. Adapun data kecenderungan berpikir kritis dikumpulkan dengan menggunakan tes the California Critical Thinking Disposition Inventori (CCTDI) yang dikembangkan oleh Facione (2011). Tes ini telah diterjemahkan ke dalam Bahasa Indonesia oleh Purwoko, dkk. (2016) 75 butir Tes objektif dengan alternatif jawaban sangat setuju, setuju, tidak setuju, dan sangat tidak setuju. Test of Basic Scientific Literacy dan tes the California Critical Thinking Disposition Inventori (CCTDI) sebelum digunakan dalam penelitian Sebelum kedua instrumen tersebut digunakan, terlebih dahulu telah dilakukan uji validitas konstruk dan validitas isi oleh 3 orang pakar instrumen. Validitas dan reliabilitas empirik butir tes dianalisis dari hasil ujicoba pada 22 siswa kelas VIII dan IX pada 2 sekolah. Hasil uji validitas dan reliabilitas butir soal menunjukkan 31 butir tes objektif dari Test of Basic Scientific Literacy yang valid dan reliabel dengan rentang rhitung antara 
0,897 - 0,457 dan nilai Cronbach's Alpha sebesar 0.934. sedangkan tes the California Critical Thinking Disposition Inventori (CCTDI), 30 butir tes objektif dinyatakan valid dan reliabel dengan rentang rhitung antara $0,854-0,427$ dan nilai Cronbach's Alpha sebesar 0.929.

Data penelitian dianalisis secara deskriptif untuk mendeskripsikan profil literasi sains dasar dan kecenderungan berpikir kritis siswa di kabupaten Sumbawa Barat. Sedangkan untuk mendapatkan gambaran tentang hubungan antara kedua aspek tersebut, data dianalisis lanjut dengan Uji Pearson Product-Moment Correlation

\section{Hasil dan Pembahasan}

\section{Profil Kemampuan Literasi Sains Dasar Siswa}

Data penelitian menunjukkan bahwa $39 \%$ siswa di Kabupaten Sumbawa Barat memiliki kemampuan literasi sains dasar pada kategori sedang (skor rata-rata antara 60-74), 35\% siswa pada kategori sangat rendah (skor rata-rata kurang dari 55) dan $17 \%$ pada kategori rendah (skor ratarata antara 55-59). Ada sekitar $10 \%$ siswa yang memiliki tingkat kemampuan literasi sains dasar pada kategori tinggi (skor rata-rata antara 75-85) dan sangat tinggi (skor rata-rata lebih dari 85. Data literasi sains dasar siswa ditinjau dari lokasi/zona sekolah, menunjukkan bahwa rata-rata skor siswa pada sekolah yang letaknya di luar kota sebesar 60,81 atau termasuk kategori sedang, dan rata-rata skor siswa di sekolah zona luar kota yakni sebesar 55,70 berada pada kategori rendah. Apabila dibandingkan rata-rata skor dari siswa laki laki dan perempuan tergambar bahwa siswa perempuan lebih memiliki kemampuan literasi sains dasar dengan skor rata-rata sebesar 60,01 (kategori sedang), dan siswa laki-laki memiliki rata-rata skor sebesar 56,32 (kategori rendah). Secara rinci, sebaran profil tingkat kemampuan literasi sains dasar disajikan pada Tabel 1 di bawah ini.

\section{Tabel 1. Distribusi Frekuensi Siswa Pada Beberapa Tingkat Kemampuan Literasi Sains Dasar Ditinjau dari Gender dan Lokasi Sekolah.}

\begin{tabular}{lllll}
\hline \multirow{2}{*}{ Kategori } & \multicolumn{4}{c}{ Distribusi } \\
\cline { 2 - 5 } & $\begin{array}{l}\text { Dalam } \\
\text { Kota }\end{array}$ & $\begin{array}{l}\text { Luar } \\
\text { Kota }\end{array}$ & $\begin{array}{l}\text { Laki- } \\
\text { laki }\end{array}$ & Perempuan \\
\hline Sangat Tinggi & 0,00 & 1,42 & 0,57 & 0,85 \\
Tinggi & 2,56 & 5,11 & 3,98 & 3,69
\end{tabular}

\begin{tabular}{|c|c|c|c|c|}
\hline Sedang & 18,47 & 20,17 & 17,61 & 21,02 \\
\hline Rendah & 9,38 & 8,24 & 7,39 & 10,23 \\
\hline Sangat Rendah & 19,60 & 15,06 & 20,45 & 14,20 \\
\hline Jumlah & 50,00 & 50,00 & 50,00 & 50,00 \\
\hline Skor Rata-rata & 55,70 & 60,81 & 56,32 & 60,01 \\
\hline
\end{tabular}

kemampuan literasi sains dasar siswa, harus dapat menjadi tolok ukur upaya menganalisis faktorfaktor penyebabnya. Beberapa faktor yang berpengaruh pada tingkat literasi sains siswa latar belakang pendidikan, dan lingkungan sekolah, pengalaman belajar dan peran orang tua (Hariadi, 2009), faktor guru, dan kemampuan membaca (Arif, et al., 2015). Selain itu faktor lain yang dapat mempengaruhi hasil leiterasi sain siswa adalah aspek pengetahuan, aspek keterampilan proses sains (kompetensi sains dan aspek sikap (Fang \& wei, 2010), senada dengan yang diutarakan oleh Wulandari \& Sholihin (2016), aspek pengetahuan (kognitif), aspek kompetensi (keterampilan proses sains), dan aspek sikap sains yang diperoleh oleh siswa selama proses pembelajaran sains merupakan komponen penting yang menentukan tingkat kemampuan literasi sains siswa.

\section{Profil Kecenderungan Berpikir Kritis Siswa Di Kabupaten Sumbawa Barat}

Secara umum, data kecenderungan berpikir kritis siswa SMP di Kabupaten Sumbawa Barat tergolong cukup baik. Sebanyak 64\% siswa memiliki tingkat kemampuan kecenderungan berpikirZ kritis dengan kategori kuat (skor rata-rata $>90$ ). Sedangkan sisanya sebanyak $34 \%$ siswa berada pada tingkat kemampuan dengan kategori positif (skor rata-rata antara 70-90), dan hanya $2 \%$

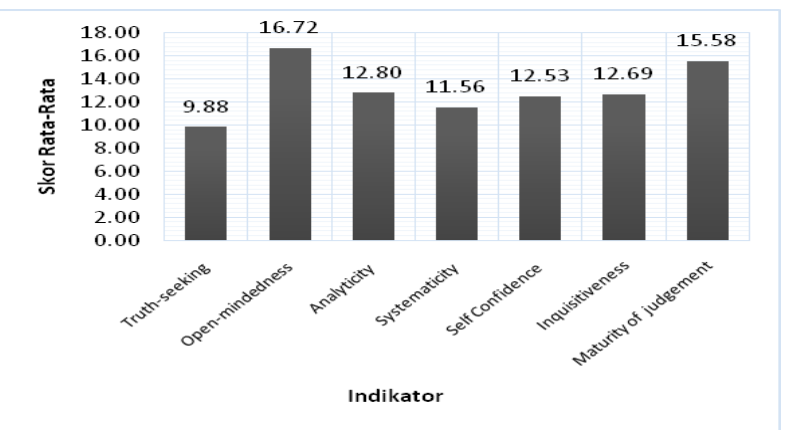

siswa pada kategori ambivalen (skor rata-rata antara 49-69). Apabila dibandingkan nilai rata-rata kecenderungan berpikir kritis dari siswa laki-laki dan siswa perempuan maka tergambar bahwa keduanya menduduki kategori kuat namun skor 
rata-rata siswa perempuan lebih besar dari pada siswa laki-laki yakni 93,13 < 90,42. Jika tinjau dari lokasi sekolah, siswa yang lokasi sekolahnya berada di luar kota dan di dalam kota sama-sama memiliki kemampuan kecenderungan berpikir kritis kuat namun nilai rata-rata sekolah yang berada di dalam kota lebih besar dibanding sekolah yang berada di luar kota yakni 91,81>91,72. Secara rinci, sebaran profil tingkat kecenderungan berpikir kritis disajikan pada Tabel 2 di bawah ini.

$\begin{array}{ll}\text { Tabel 2. Distribusi } & \begin{array}{c}\text { Frekuensi } \\ \text { Beberapa Siswa Pada }\end{array} \\ \text { Berpikir Kritis Ditinjau dari Gender } \\ \text { dan Lokasi Sekolah. }\end{array}$

\begin{tabular}{lllll}
\hline \multirow{2}{*}{ Kategori } & \multicolumn{5}{c}{ Distribusi Frekuensi (\%) } \\
\cline { 2 - 5 } & $\begin{array}{l}\text { Dalam } \\
\text { Kota }\end{array}$ & $\begin{array}{l}\text { Luar } \\
\text { Kota }\end{array}$ & $\begin{array}{l}\text { Laki- } \\
\text { laki }\end{array}$ & $\begin{array}{l}\text { Perempua } \\
\text { n }\end{array}$ \\
\hline \multirow{2}{*}{ Kuat } & 31.53 & $\begin{array}{l}32.3 \\
9\end{array}$ & $\begin{array}{l}28.6 \\
9\end{array}$ & 35.23 \\
Positif & 17.90 & $\begin{array}{l}16.1 \\
9\end{array}$ & $\begin{array}{l}19.8 \\
9\end{array}$ & 14.20 \\
Ambivalen & 0.57 & 1.42 & 1.42 & 0.57 \\
Negatif & 0.00 & 0.00 & 0.00 & 0.00 \\
\hline Jumlah & 50.00 & $\begin{array}{l}50.0 \\
0\end{array}$ & 50.0 & 50.00 \\
\hline $\begin{array}{l}\text { Skor Rata- } \\
\text { rata }\end{array}$ & 91.87 & $\begin{array}{l}91.7 \\
2\end{array}$ & 90.4 & 93.13 \\
\hline \multicolumn{5}{c}{ Apabila } \\
\hline
\end{tabular}

kecenderungan berpikir kritis dari siswa laki-laki dan siswa perempuan maka tergambar bahwa keduanya menduduki kategori kuat namun skor rata-rata siswa perempuna lebih besar dari pada siswa laki-laki yakni 93,13<90,42. Jika tinjau dari lokasi sekolah, siswa yang lokasi sekolahnya berada di luar kota dan di dalam kota sama-sama memiliki kemampuan kecenderungan berpikir kritis kuat namun nilai rata-rata sekolah yang berada di dalam kota lebih besar dibanding sekolah yang berada di luar kota yakni 91,81>91,72. Hasil penelitian ini mengindikasikan bahwa kecenderungan berpikir kritis siswa SMP di kabupaten Sumbawa Barat, cenderung tidak stabil.

Tinjauan kemampuan siswa berdasarkan indikator kecenderungan berpikir kritis, menunjukkan bahwa skor rata-rata tertinggi diperoleh pada indikator Open-Mindednes yakni

16,72 , sedangkan yang terendah pada indikator Truth-Seeking yakni sebesar 9,88. Skor rata-rata per indikator disajikan pada Gambar 1:
Gambar 1. Distribusi Skor Rata-Rata Siswa Pada Setiap Indikator Kecenderungan Berpikir Kritis

Berdasarkan data pada Gambar 1, terlihat bahwa pada indikator Truth-Seeking memiliki ratarata skor kecenderungan berpikir kritis terendah. Fakta ini mengindikasikan bahwa siswa pada umumnya belum memiliki rasa keingintahuan yang kuat terhadap kebenaran atas suatu situasi. Siswa dengan rasa ingin tahu yang rendah cenderung untuk menerima sesuatu tanpa mampu memberikan alasan atau bukti yang membenarkan mereka dalam menerima atau menolak sesuatu hal/situasi yang dihadapi. Hasil penelitian sejalan dengan temuan Salsali, et al., (2013) yang menyatakan bahwa siswa sekolah perawat kesehatan di negara-negara Asia memiliki kecenderungan berpikir kritis lebih rendah dari siswa lain di Negara-negara selain Asia. Siswa dengan rasa ingin tahu yang rendah juga cenderung kurang mampu mengevaluasi informasi dan bukti untuk mencari suatu kebenaran dari suatu situasi.

Adanya fakta tentang rendahnya kemampuan kecenderungan berpikir kritis siswa pada indikator Truth-Seeking, harus dapat dijadikan bahan evaluasi untuk menganalisis faktor-faktor penyebab masalah tersebut. Menurut Akgun \& Duruk (2016) kecenderungan berpikir kritis berkembang atas dasar lingkungan social dan hubungan antara berbagai komponen lingkungan. Senada dengan Harasym, dkk. (2008) yang menjelaskan bahwa peningkatan kecenderungan berpikir kritis memprasyaratkan terpenuhi faktor-faktor yang mendukung berkembangnya kecenderungan berpikir kritis oleh komponen sistem pendidikan yang berlaku (pembelajaran, guru, model kurikulum, suasana atau lingkungan belajar).

Berdasarkan temuan ini, diharapkan komunitas pendidik sains khususnya di kabupaten Sumbawa Barat harus memberikan perhatian penuh pada hubungan timbal balik antara pendidikan formal di jenjang sekolah dasar, jenjang sekolah menengah, dan pendidikan tinggi dengan literasi sains yang harus dikuasai oleh peserta didik (Laugksch, 1999). Sehubungan dengan pentingnya peran guru dalam memfasilitasi berkembangnya literasi sains dan kecenderungan berpikir kritis siswa, maka perlu ada upaya serius dan 
berkelanjutan untuk mengembangkan kompetensi literasi sains guru dan keterampilan berpikir guru, khususnya guru-guru IPA di Kabupaten Sumbawa Barat.

\section{Hubungan antara literasi sains dasar dengan kecenderungan berpikir kritis siswa}

Hubungan antara literasi sains dasar dengan kecenderungan berpikir kritis siswa dapat dilihat dari hasil Uji Pearson Product-Moment Correlation seperti yang ditunjukkan pada Tabel 1 di bawah ini:

\begin{tabular}{lcccl}
\hline Variabel & N & Mean & S.Dev. & r \\
\hline $\begin{array}{l}\text { Literasi sains } \\
\text { dasar }\end{array}$ & 347 & 58.6965 & 13.73928 & $993^{* *}$ \\
$\begin{array}{l}\text { Kecenderungan } \\
\text { berpikir kritis }\end{array}$ & 333 & 92.6156 & 6.12146 & $993^{* *}$ \\
\hline
\end{tabular}

**. Correlation is significant at the 0.01 level (2tailed).

Tabel 1 di atas menunjukkan nilai signifikansi sebesar 0,00 lebih kecil dari 0,05 maka dapat diartikan bahwa terdapat hubungan antara literasi sains dasar dengan kecenderungan berpikir kritis. Untuk melihat derajat hubungan antara literasi sains dasar dengan kecenderungan berpikir kritis dapat diketahui dari nilai Pearson Correlation yakni sebesar 0,993 yang artinya derajat hubungan antara literasi sains dasar dengan kecenderungan berpikir kritis tergolong korelasi sempurna karena nilai Pearson Correlation tersebut berada pada rentang 0,81 - 1,00. Selain itu, dari hasil Uji Pearson Product-Moment Correlation tersebut juga diketahui pola hubungan literasi sains dasar dengan kecenderungan berpikir kritis yakni dari nilai Pearson Correlation yang positif dapat diartikan bahwa apabila kemampuan literasi sains dasar siswa meningkat maka kemampuan kecenderungan berpikir kritis siswa juga pasti meningkat. Senada dengan pernyataan Rahayuni (2016), keterampilan berpikir kritis merupakan salah satu faktor kognitif yang mempengaruhi literasi sains. Bila keterampilan berpikir keritis peserta didik baik, maka kemampuan literasi sainsnya juga akan baik. Dalam hal ini Vieira \& Vieira (2016) menyatakan bahwa kerangka teoritis yang digunakan oleh para guru harus relevan dan praktis untuk mengembangkan pengalaman belajar siswa agar mampu memfasilitasi perkembangan kemampuan berpikir kritis dan dal literasi sains siswa.

\section{Kesimpulan}

Kesimpulan harus mengindikasi secara jelas hasil-hasil yang diperoleh, kelebihan dan kekurangannya, serta kemungkinan pengembangan selanjutnya.

Kesimpulan dapat berupa paragraf, namun sebaiknya berbentuk point-point dengan menggunakan numbering atau bullet.

Profil kemampuan literasi sains dasar dan kecenderungan berpikir kritis siswa adalah: siswa di Kabupaten Sumbawa Barat memiliki kemampuan literasi sains dasar yang tergolong rendah yakni $39 \%$ diantaranya pada kategori sedang, 35\% siswa pada kategori sangat rendah, $17 \%$ pada kategori rendah dan kurang dari $10 \%$ siswa yang memiliki tingkat kemampuan literasi sains dasar pada kategori Tinggi ataupun sangat tinggi. Sedangkan kecenderungan berpikir kritis siswa di Kabupaten Sumbawa Barat berada pada kategori kuat, yakni Sebanyak $64 \%$ siswa memiliki tingkat kemampuan kecenderungan berpikir kritis dengan kategori kuat, $34 \%$ siswa berada pada kategori positif , dan hanya $2 \%$ siswa pada kategori ambivalen.

Selain itu, dapat diketahui bahwa terdapat hubungan yang signifikan antara literasi sains dasar dengan kecenderungan berpikir kritis yang tergolong korelasi sempurna dan bersifat positif dengan nilai signifikansi sebesar 0,00 dan Pearson Correlation sebesar 0,993.

Guru sebagai komponen sistem pendidikan sangat dibutuhkan dalam memfasilitasi berkembangnya literasi sains dan kecenderungan berpikir kritis siswa, maka perlu ada upaya serius dan berkelanjutan untuk mengembangkan kompetensi literasi sains guru dan keterampilan berpikir guru, khususnya guru-guru IPA di kabupaten Sumbawa Barat.

\section{Daftar Pustaka}

Akgun,A., dan U. Duruk. 2016. The Investigation of Preservice Science Teachers' Critical Thinking Dispositions in the Context of Personal and Social Factors. Science Education International. Vol. 27 No. 1, pp: 3-15

Ardianto, Didit \& Rubini, Bibin. 2016 Literasi Sains dan Aktivitas Siswa Pada Pembelajaran IPA Terpadu Tipe SHARED. 
Unnes Science Education Journal (ISSN: 2502-6232), Vol. 5 (1) pp: 1167-1174.

Arif Rachmatullah, Sariwulan Diana, Nuryani Y. Rustaman. 2015. Profile of Middle School Students on Scientific Literacy Achievements by Using Scientific Literacy Assessments (SLA). Proceedings of International Seminar on Mathematics, Science, and Computer Science Education (MSCEIS 2015).

Arohman, M., Saefudin, dan Priyandoko, D. 2016. Kemampuan Literasi Sains Siswa Pada Pembelajaran Ekosistem. Proceeding Biology Education Confrerence (ISSN: 25285742, Vol. 13 No.1 pp: 90-92.

Badan Standar Nasional Pendidikan. 2010. Paradigma Pendidikan Nasional Abad XXI. Tim Paradigma Pendidikan.

Facione, A. 2011. Critical Thinking: What It Is and Why It Counts. Milbrae: Measured reasons and The California Academic Press.

Facione, P.A, (Giancarlo) CA, Facione NC, Gainen J. 1995. The Disposition towards Critical Thinking. Journal of General Education. Vol. 44 No. 1 pp: 1-25.

Fakhriyah, F., S. Masfuah, M. Roysa, A. Rusilowati, E. S. Rahayu. 2017. Student's science literacy in the aspect of content science? Jurnal Pendidikan IPA Indonesia, Vol: 6 No.1 pp: 81-87.

Fang, Z \& Wei. 2010. Improving Middle School Student's Literacy Through Reading Infusion. The Jurnal of Education Research. Vol. 103 No.4 pp: 262-273

Harasym PH, Tsai TC, Hemmati P. 2008. Current Trends In Developing Medical Students' Critical Thinking abilities. Kaohsiung J Med Sci. Vol. 24 No.7 pp: 341-355.

Hariadi, E. (2009). Faktor-faktor yang Mempengaruhi Literasi Sains Siswa Indonesia Berusia 15 Tahun. Pendidikan Dasar, Vol. 10 No. 1.
Kwon, N., Anthony J. Onwuegbuzie, and Linda Alexander. 2007. Critical Thinking Disposition and Library Anxiety: Affective Domains on the Space of Information Seeking and Use in Academic Libraries. College \& Research Libraries. Vol 68 No. 3 pp: $268-278$.

Laugksch, R.C. \& Spargo P.E. 1996. Construction of a paper-and-pencil Test of Basic Scientific Literacy based on selected literacy goals recommended by the American Association for the Advancement of Science. Public Understanding of Science, Vol. 5 No. 4 pp: 331-359.

OECD. 2006. Assessing Scientific, Reading and Mathematical Literacy A Framework for PISA 2006. Diunduh dari http://edu. au.dk/fileadmin/ www. dpu. dk/omdpu. Diunduh tanggal 16 Agustus 2010.

OECD. 2009a. Results: What Students Know and Can Do Student Performance in Reading, Mathematics and Science. Diunduh dari http://www.oecd.org/ pisa/2548.pdfpisaproducts/4885. Diunduh tanggal 6 Februari 2015.

OECD. 2009b. "Science Sample Tasks", in Take the Test: Sample Questions from OECD's PISA Assesments, OECD Publishing. Diunduh dari http://www.oecd.org/pisa/2548.pdfpisaprod ucts/488597826 4050815-5-en. Tanggal 5 Maret 2015.

OECD, 2012. PISA 2012 Results in Focus. What 15-year-olds Know and What They Can Do with What They Know. Diunduh dari www.oecd.org/pisa-2012-results.htm. Diunduh tanggal 6 Februari 2015.

Purwoko, A.A., Andayani Y., dan Muntari. 2016. Pengembangan Instrumen Penilaian untuk Mendiagnosis Kecenderungan Berpikir Kritis Mahasiswa Program Studi Pendidikakan Kimia. Universitas Mataram. Laporan penelitian. Tidak dipublikasi.

Rahayuni Galuh. 2016. Hubungan Keterampilan Berpikir Kritis dan Literasi Sains Pada 
Pembelajaran IPA Terpadu dengan model PBM dan STM. JPPI, Vol. 2, No. 2 pp: 131146.

Salsali, Mahvash., Mansooreh Tajvidi \& Shahrzad Ghiyasvandian. 2013. Critical Thinking Dispositions of Nursing Students in Asian and Non-Asian Countries: A Literature Review. Global Journal of Health Science; Vol. 5, No. 6; 2013

Tafazzoli M, Rashidi Fakari F, et al. 2015. The Relationship Between Critical Thinking Dispositions and Academic Achievement In Iranian Midwifery Students. Nurs Pract Today. 2015; 2(3) pp: 88-93.

Vieira, R.M \& Celina Tenreiro-Vieira. 2016. Fostering Scientific Literacy and Critical Thinking in Elementary Science Education. International Journal of Science and Math Education, Vol. 14 pp: 659-680

Wulandari, N \& Sholihin, H. 2016. Analisis Kemampuan Literasi Sains pada Aspek Pengetahuan dan Kompetensi Sains Siswa SMP pada Materi Kalor. EDUSAINS, Vol. 8 No.1 pp: 66-73 